\title{
APPLICATION OF FRAMING IN LEADERSHIP COMMUNICATION: A SYSTEMATIC REVIEW AND RESEARCH AGENDA
}

\author{
Chandan R Honavar ${ }^{* 1} \bowtie$, Krishna Bhargav K L ${ }^{* 1}$, Dr Theresa Nithila Vincent ${ }^{* 1}$ \\ ${ }^{* 1}$ School of Commerce Finance and Accountancy, CHRIST (Deemed to be University), India
}

DOI: https://doi.org/10.29121/ijetmr.v7.i11.2020.817

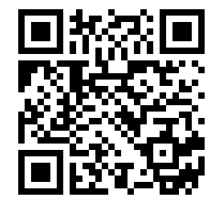

Article Citation: Chandan R Honavar, Krishna Bhargav K L, and Dr Theresa Nithila Vincent. (2020). APPLICATION OF FRAMING IN LEADERSHIP COMMUNICATION: A SYSTEMATIC REVIEW AND RESEARCH AGENDA. International Journal of Engineering Technologies and Management Research, 7(11), 39-49.

https://doi.org/10.29121/ijetmr.v7 i11.2020.817

Published Date: 24 November 2020

Keywords:

Framing

Framing Effect

Framing Theory

Leadership Communication

Application of Framing

\begin{abstract}
Under various fields of research, framing is a concept beautifully constructed by the diverse set of theories and notions. Framing is all about how an individual, a group, an organization or the society communicates and perceives a particular issue. Fields such as Media and communication, Health, Politics and law saw the advent of applications of framing. Due to increased burnout among employees and conflicts between leaders and employees, the need and importance of framing have raised in the area of Leadership communication. In any organization, leaders should be aware of the importance of framing for effective communication. This paper reflects the comprehensive review of the 'framing' concept and also the methodological procedures used in empirical studies of framing, leading to a discussion of how framing could be used in Leadership Communication. Researchers and Academicians can use this literature review to develop a model or frame policies to train individuals involved in leadership roles to use framing as a skill.
\end{abstract}

\section{INTRODUCTION}

Most successful people in the world have mastered the art of communication. Human resource is the most valued resource for an organization, but it is the most difficult to manage and control. A superior form of communication strategy (Strategic Communication) must be employed to harness the human mind and direct to elicit the desired action. In the competitive corporate world, Individuals are ignorant about effective communication. This article strives to analyze the applications of framing in various fields and how it can be applied in Leadership communication to achieve the benefits.Fairhurst (2011) states that communication is a skill, an underlying capability to act. When considered as a skill, framing refers to be able to communicate coherently and in a persuasive manner according to the situation's needs. Framing is one of the popular ways of communication. Businesspersons seldom use the ability to persuade as it consumes time to persuade another effectively. Trust between the speaker and the receiver of information is crucial. However, without common ground and evidence that compels the audience to enable the speaker to connect emotionally (Conger, 1998). Constant Learning has more significance than ever today as learners need to upskill and reskill themselves to stay ahead of the curve. Leaders are to be trained to enhance the experience of learning. Learning and development, a branch of HR, focusses on improving team and individual

(C) 2020 The Author(s). This is an open access article distributed under the terms of the Creative Commons Attribution License, which permits unrestricted use, distribution, and reproduction in any medium, provided the original author and source are credited. 
functioning by developing knowledge and skills. It is an integral part of talent acquisition and management action plan and is conceived to arrange individual as well as group goals with the organization's vision/goals. As global human capital has been evolving, the need for upskilling and reskilling is imperative. According to Training Magazine's Report, companies in the US spent an aggregate of $\$ 90$ billion on training and development in 2017. Many experts draw attention to the benefits of employee training and development, resulting in better employee engagement and retention. However, critics point out that such investment is rarely successful. Many leaders consider that training solves various behavioural problems and assists in learning new skills. While this is the classic theory prevalent, the reality is often disappointing. Training programs make employees more trainable than entrepreneurial (Carucci, 2018). The organization focuses more on freelancers as an extended workforce. Millennials have a distinct perception of workforce learning, especially that life-long learning is an essential and critical part of the workplace. According to Deloitte's Bersin division working on employee development, more than 35 million employees are being enrolled on MOOCs like eDX, Coursera and Udemy and trained on courses required for the workplace as well as other courses at Bersin in 2015. This led to cross-disciplinary learning in the organization. Organizations are reconsidering the human resources they need to invest in this highly competitive global environment. The approach organizations choose to train their employees needs to be rethought (Younger, 2016). It often happens that people believe self-confident amateurs than experts. The access to the internet has increased the number of social media influencers and propaganda of politicians on social media due to which publishers are speaking more often about the art of persuasion. Effective influencers set up the audience's mind a certain way and then use their persuasive skills to match up to the audience's state wherein they look for a longterm gain than short-term agreement. Being empathic goes a long way in being influential as the audience connects with the speaker. Generally, being a person who gives things away like a critical piece of information or valuable advice makes one appealing. The art and science of persuasion had become a fundamental skill than a soft skill. From Aristotle to Hitler to Steve Jobs, communication and presentation as speakers played a vital role in their effectiveness as leaders or communicators (Harrell, 2019). The objective of this paper is to present multiple fields of applications of framing as perceived by the respective authors. Furthermore, to pinpoint that leaders need framing training as a part of their training process to become agile leaders.

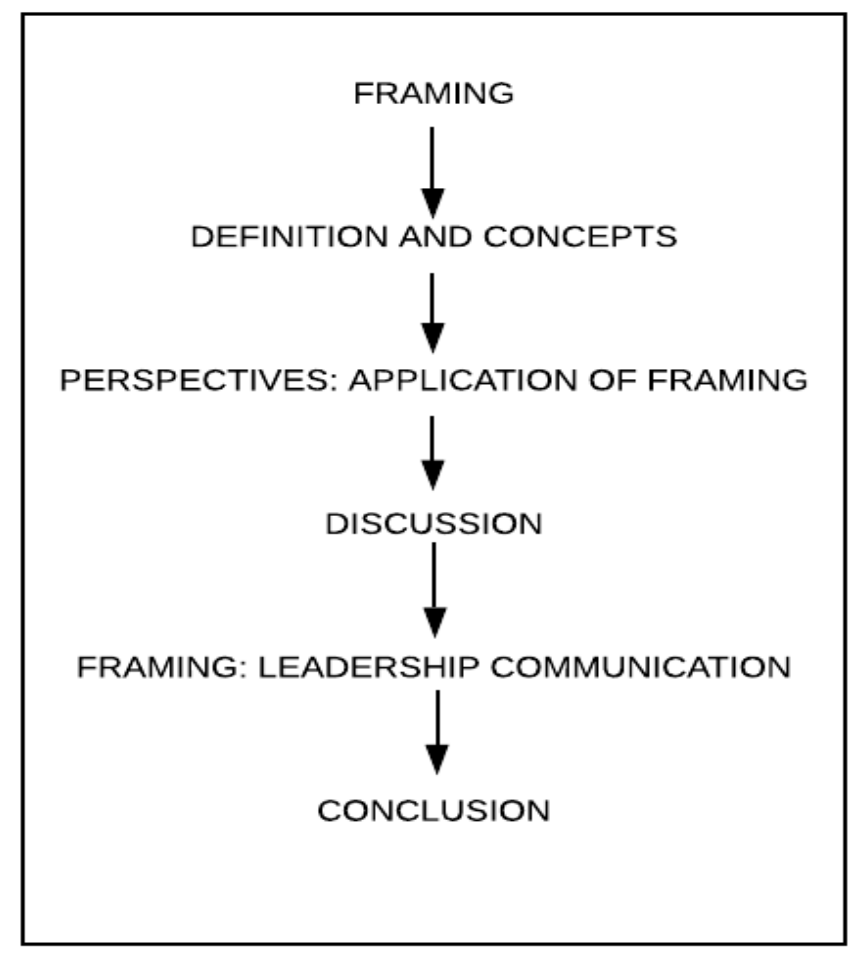

Figure 1: CONCEPTUAL FRAMEWORK 


\section{FRAMING: DEFINITIONS AND CONCEPTS}

Applications of framing have occurred in various other fields where communication plays a vital role such as Marketing, Mass media, Health sector, Finance, Politics and Law. However, this paper is focussed on five significant areas where framing influences the way people process information. Framing can be used in forms of a metaphor, stories with a specific focus, cultural traditions, value judgements of positive or negative with inherent bias or even by presenting a concept with contrast (Theory, 2011). Framing is highly related to the idea of agenda-setting. Framing theory suggests that the media pays particular attention to one topic and then presents it within a field or frame to the public. They influence not only what to think, even how to think about the issue (Arowolo, 2017).

For example, the perceived gain effect is achieved through the display of nine-ending price in the market. This led to findings that gain-framed messages are more likely to increase the purchase likelihood of the product than a loss-framed message along with a nine-ending price (Choi, Lee, \& Ji, 2012).In smoking cessation research, the fear appeal gains more focus than any other approach. This study compares the effect of a positively-framed message to that of negatively-framed message on the attitude of smokers. Linear structural modelling was used to reveal that framing the message influenced different mental processes. In closure, the positively-framed message was highly effective in smoking cessation (Benjamin A. Toll, 2008). Public Service Announcements are a medium adopted to reduce binge drinking. This study focusses on the message framing to reduce undesired behaviour among bystanders than drinkers and fills a gap in research by examining the different reference points as to how it affects others and self-others (Li \& Rifon, 2017).The success of the gain-framed and loss-framed messages are dependent on how much the message recipient is affected. This study showed that loss-framed words are more effective than gain-framed messages when it comes to subjects' intentions to engage in health care to undertake preventive measures even though objectives are specified in both the notes (Punam Anand Keller I. M., 2003). Framing the message is more important than the actual message conveyed. Adding personal meaning to the message is quintessential. The better the frame, higher is the impact on the receiver of the message, and it helps avoid the noise surrounding the message. The conscious effort to have a goal in one's mind purposely helps one to manage to mean unconsciously while communicating (Honig-Haftel, 1996). However, if an individual is vulnerable to framing effects, their consent is irrelevant. There is a possibility that problems will occur with the non-consequentialist people concerning their view of consent. Framing effects seem to be cumbersome as believing that the permissibility of any act can be based on how a question is asked, rather than the content of the issue. An analysis of 1,415 magazine advertisements about whether the ads were framed or unframed, when the material was characterized or not characterized or when the product advertised was searched or experience good. Framed ads, described content dominate and unframed advertisements used more often with marked content (Shimp, Urbany, \& Camlin, 2013).

Table 1: Definitions and Concepts

\begin{tabular}{|c|c|}
\hline Author(s) & Definition \\
\hline $\begin{array}{l}\text { (Entman, } \\
1993)\end{array}$ & $\begin{array}{l}\text { "To frame is to select some aspects of a perceived reality and make them more salient in a } \\
\text { communicating text, in such a way as to promote a particular problem definition, causal } \\
\text { interpretation, moral evaluation, and/or treatment recommendation for the item described" }\end{array}$ \\
\hline $\begin{array}{l}\text { (McCombs, } \\
\text { 1997) }\end{array}$ & $\begin{array}{l}\text { "framing is the selection of a restricted number of thematically related attributes for inclusion } \\
\text { on the media agenda when a particular object is discussed." }\end{array}$ \\
\hline (Gorp, 2007) & $\begin{array}{l}\text { "framing incorporates a wider range of factors than priming and agenda-setting, which are both } \\
\text { cognitive concepts," and that "frames are tied in with culture as a macro societal structure." }\end{array}$ \\
\hline $\begin{array}{l}\text { (Theory, } \\
\text { 2011) }\end{array}$ & $\begin{array}{c}\text { "draw attention to certain attributes of the objects of news coverage, as well as to the objects } \\
\text { themselves" }\end{array}$ \\
\hline
\end{tabular}

Though framing has a broader range than just one issue; however, framing studies develop frames related to a single point. Figurative framing includes metaphor, hyperbole and irony, which help shape public discourse as they involve prominent conceptual and linguistic content. Metaphor, hyperbole and irony are focused at societal issues and then towards the complexity of the mentioned types of figurative framing (Burgers, Konijn, \& Steen, 2016).

Positive framing highlights the benefits, while negative framing highlights the risk arising out of products (Tversky \& Kahneman, 1981). Intuitive as well as deliberative system are two reasoning systems that can result in a 
framing effect. Deliberate is rational, analytical and calculative, whereas the intuitive system is spontaneous and emotional (Kahneman \& Frederick, 2002).

Philosophical arguments in social constructionism over relativism, essentialism, and agency draw boundaries around that which is open to framing and that which is not. According to O'Keefe's (1998) theory of "Message Design Logics", the logics which managers utilize to produce and receive messages impacts framing capability. There is always an insecurity of whether framing is a teachable skill and the contingencies associated with active learning. Possible reasons for failure to understand 'framing' are

- Uncertainty about an 'as if 'world

- Message Design Logics

For the purpose of our research, we have limited the concept of framing to just goal framing rather than agendasetting, priming or evenprospect theory. From the above review, we can understand that Framing is more to do with how one communicates and how much information is contained in the message conveyed. It is a skill which can be honed just like any other by anyone over time with practice and application.

\section{METHODOLOGICAL APPROACH}

Literature Reviews primarily throw light on theoretical concepts, the scope for further research and to present the list of sources utilized (Rowley \& Slack, 2004). First, we identified the topics to be included in our study. We added more keywords to our search list to find a gap in our review of applications of framing.

\section{IDENTIFICATION AND SELECTION OF PAPERS TO REVIEW}

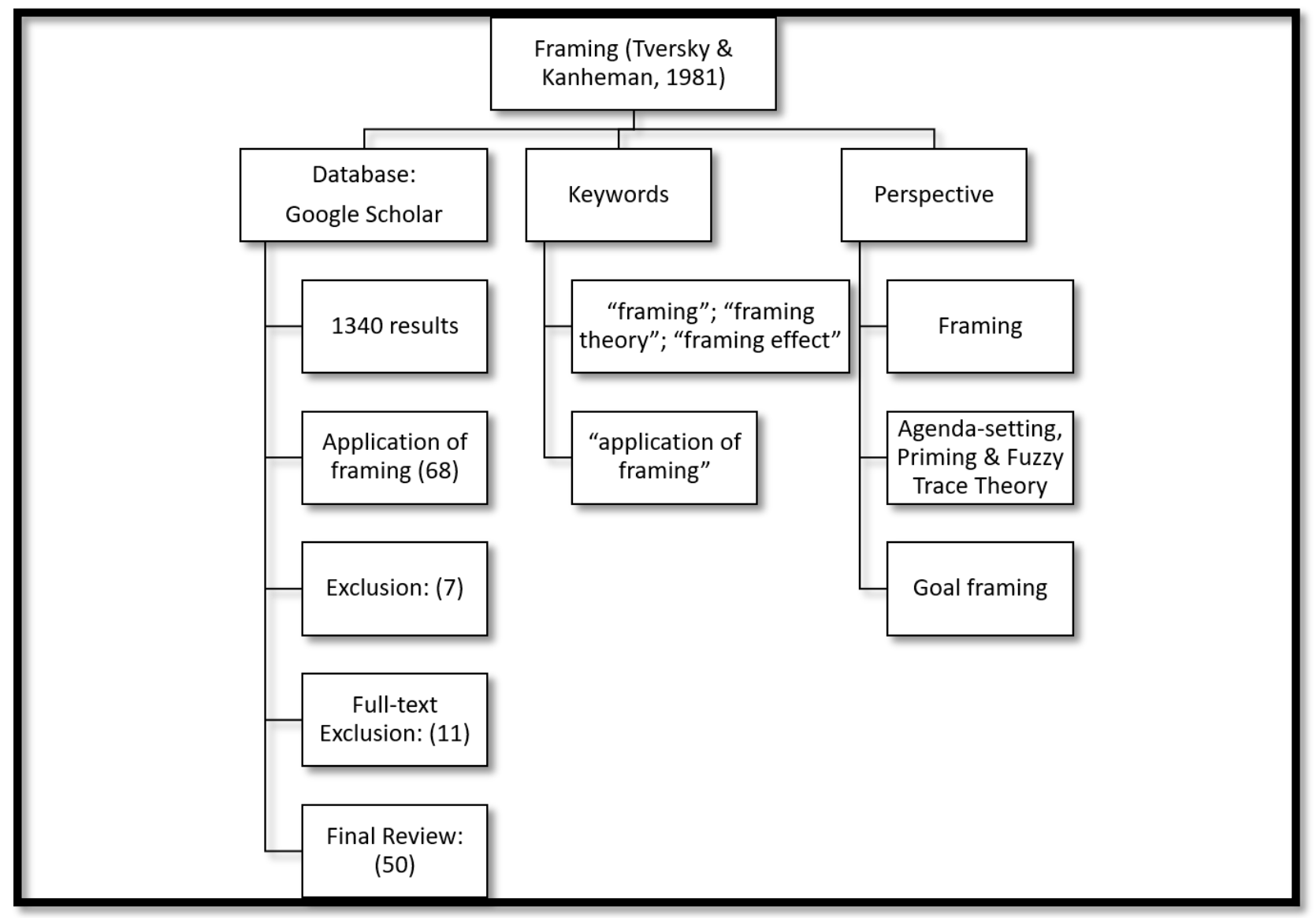

Figure 2: Methodological Approach 
Tversky and Kanheman (1981) pioneered in the research study of the applications of framing. However, framing was postulated in 1972 (Arowolo, 2017). After reviewing the original articles, we adopted a search for materials with a broader perspective. The concept of framing emerged in the 1990s to be a dominant period of study of framing and related ideas. We used Google Scholar as the Database as it covers all other databases under the search engine. Initially, we obtained a total of 1340 results in Google Scholar, when the search keywords were "framing", "framing theory" and "framing effect" as given in Figure 2. However, as we reviewed specific papers, we found thatthe applications of framing is unexplored. So, the keyword "application of framing" was added. Specific articles stated framing from a distinct perspective than what we required. So, based on the content in the articles, 68 articles were downloaded with a broader perspective on framing which includes concepts like agenda-setting, priming, fuzzy trace theory. Based on screening, we excluded seven articles which dealt with framing discursively as we included goal-framing as our focus of study. Out of the remaining 61 articles, 11 articles were excluded as a part of full-text exclusion as the articles did not support our study. The remaining 50 articles were classified into two parts i.e. one, the articles which could be used for literature review and the rest of the articles for Table 2 . So, 18 articles were deemed as empirical studies required for the study and the rest were used for literature purposes.

Table 2: Perspectives on The Application of Framing

\begin{tabular}{|c|c|c|c|}
\hline Category & Author(s) & Methodology & Findings \\
\hline Health & Dong Jenn Yang & $\begin{array}{l}\text { Structural } \\
\text { Equation } \\
\text { Modeling }\end{array}$ & $\begin{array}{l}\text { (1) Various driving sources, mental processes and } \\
\text { excellent communication can be provoked by message } \\
\text { framing, which also depends on agency thinking, (2) To } \\
\text { promote the stoppage of smoking, a positively-framed } \\
\text { message is tested to be effective. }\end{array}$ \\
\hline Health & $\begin{array}{l}\text { Adam D Koon, } \\
\text { Benjamin Hawkins } \\
\text { and Susannah H } \\
\text { Mayhew }\end{array}$ & $\begin{array}{l}\text { Arksey and } \\
\text { O'Malley } \\
\text { framework for } \\
\text { Scoping Review }\end{array}$ & $\begin{array}{l}\text { Not many studies are explicitly conducted on heath } \\
\text { policy framing. Most of the studies commonly pointe out } \\
\text { "constructivist epistemology". Homelessness, Injection } \\
\text { drug use, assisted reproductive technologies may be } \\
\text { reframed as "health issues". }\end{array}$ \\
\hline Health & $\begin{array}{c}\text { Chia-Yen Lin and } \\
\text { Wei-Ju Yeh }\end{array}$ & $\begin{array}{l}\text { Two Factor } \\
\text { Multivariate } \\
\text { Analysis to test } \\
\text { Hypotheses }\end{array}$ & $\begin{array}{l}\text { Regulatory Focus and Message framing were converged } \\
\text { to identify attitude to health advertisements and } \\
\text { behavioural intentions towards healthy eating. The } \\
\text { direct publication is possible to persuade consumers to } \\
\text { change their behaviour when message framing matches } \\
\text { the regulatory focus of the recipient. }\end{array}$ \\
\hline Health & $\begin{array}{l}\text { Kang Li and Nora } \\
\text { Rifon }\end{array}$ & $\begin{array}{l}\text { Structural } \\
\text { Equation } \\
\text { Modeling }\end{array}$ & $\begin{array}{l}\text { Message Framing: Loss vs Gain and Referencing Points } \\
\text { (Self-other referencing and Other referencing } \\
\text { experiment was conducted to find that Self-other } \\
\text { referencing led to higher possibility in intentions of } \\
\text { bystander intervention than a message with other } \\
\text { referencing, Self-other referencing leads to students } \\
\text { having more involvement with advertisements than } \\
\text { public service announcements and Gender was a } \\
\text { significant factor leading to engagement with ads. }\end{array}$ \\
\hline Marketing & $\begin{array}{l}\text { Punam Anand } \\
\text { Keller, Isaac M. } \\
\text { Lipkus and } \\
\text { Barbara K. Rimer }\end{array}$ & MANOVA & $\begin{array}{l}\text { Participants convinced to have a positive mood believe } \\
\text { more in loss-framed messages, whereas the participants } \\
\text { with a negative attitude are prompted with the gain- } \\
\text { framed words. }\end{array}$ \\
\hline Marketing & $\begin{array}{c}\text { Ma. Criselda M. } \\
\text { Tengco-Pacquing, } \\
\text { Racquel N. } \\
\text { Bustamante, } \\
\text { Andrea Patricia E. } \\
\text { Cabanban, Mary }\end{array}$ & $\begin{array}{l}\text { Positive } \\
\text { Framing Effect } \\
\text { Survey }\end{array}$ & $\begin{array}{l}\text { A noteworthy distinction in the kind of positive framing } \\
\text { effect states that Filipino millennials like decisive goal } \\
\text { framing better. Themes identified frugality and instant } \\
\text { gratification explain why positive goal framing is } \\
\text { preferred while product truth and rationality states } \\
\text { otherwise. }\end{array}$ \\
\hline
\end{tabular}




\begin{tabular}{|c|c|c|c|}
\hline & $\begin{array}{l}\text { Bernadette M. } \\
\text { Cesare Vince } \\
\text { Andre Christopher } \\
\text { C. Gamez }\end{array}$ & & \\
\hline Marketing & $\begin{array}{l}\text { Irwin P. Levin and } \\
\text { Gary J. Gaeth }\end{array}$ & ANOVA & $\begin{array}{l}\text { (1) The scope which differentiates the "label-only" } \\
\text { condition of the } 1987 \text { Levin study and the "taste plus } \\
\text { labelling" of the present-day research, (2) The scope } \\
\text { which defines the difference between the "taste after } \\
\text { labelling" and "taste before labelling" circumstances of } \\
\text { the present-day study }\end{array}$ \\
\hline Marketing & $\begin{array}{l}\text { Stefan F. } \\
\text { Bernritter, Iris van } \\
\text { Ooijen and } \\
\text { Barbara C.N. } \\
\text { Müller }\end{array}$ & $\begin{array}{l}\text { Fourth-spread } \\
\text { outlier test, } \\
\text { Moderation } \\
\text { Analysis }\end{array}$ & $\begin{array}{c}\text { Compared to direct persuasion, self-persuasion attempts } \\
\text { will increase consumers' (customers with greater } \\
\text { involvement) abundance. }\end{array}$ \\
\hline $\begin{array}{l}\text { Mass } \\
\text { Media }\end{array}$ & $\begin{array}{l}\text { Terence A. Shimp, } \\
\text { Joel E. Urbany and } \\
\text { Sarah E. Camlin }\end{array}$ & $\begin{array}{l}\text { Content } \\
\text { Analysis based } \\
\text { on Hypotheses } \\
\text { tests }\end{array}$ & $\begin{array}{l}\text { The major part of the findings of this paper has } \\
\text { implications on the research started by Edell and Staelin } \\
\text { and Nelson's "Theory of advertising and information". In } \\
\text { this paper, Magazine advertisements were studied for } \\
\text { their structural characteristics being framed or } \\
\text { unframed; the content available was analyzed by } \\
\text { segregating them into characterized and non- } \\
\text { characterized material. At the same time, the products } \\
\text { advertised were differentiated based on search and } \\
\text { experience goods. Findings suggest that most } \\
\text { advertisements in magazines are framed and } \\
\text { characterized. However, when the marked content is for } \\
\text { experience goods, unframed ads are best suited. }\end{array}$ \\
\hline $\begin{array}{l}\text { Mass } \\
\text { Media }\end{array}$ & $\begin{array}{l}\text { Thomas E. Powell, } \\
\text { Hajo G. } \\
\text { Boomgaarden, } \\
\text { Knut De Swert \& } \\
\text { Claes H. de Vreese }\end{array}$ & $\begin{array}{l}\text { Experiments } \\
\text { using Cognition } \\
\text { and Affect } \\
\text { Scales }\end{array}$ & $\begin{array}{l}\text { Two separate political issues were tested using } \\
\text { experiments, and the result stated that automatic and } \\
\text { controlled processing favours the effects of visual and } \\
\text { text media. While manipulations made in the } \\
\text { experiments showed similar results, individual data gave } \\
\text { a distinct result than expected out of multimodal effects. }\end{array}$ \\
\hline $\begin{array}{l}\text { Mass } \\
\text { Media }\end{array}$ & $\begin{array}{c}\text { BERTRAM } \\
\text { SCHEUFELE }\end{array}$ & $\begin{array}{l}\text { Content } \\
\text { Analysis with a } \\
\text { specific focus on } \\
\text { Definitions and } \\
\text { Methods }\end{array}$ & $\begin{array}{l}\text { Field studies depend on the summation of data available, } \\
\text { and Experiments make use of real impetus which is } \\
\text { affected by other attributes, Researchers focussing on } \\
\text { "agenda-setting" approach depict that they affect the } \\
\text { victims aggressively; however, the issue being studied is } \\
\text { essential. "Media-framing" first persuades the cognitions } \\
\text { and later the behaviour of the recipients. }\end{array}$ \\
\hline $\begin{array}{l}\text { Mass } \\
\text { Media }\end{array}$ & $\begin{array}{l}\text { Vanessa G. Perry, } \\
\text { Carol M. Motley } \\
\text { and Robert L. } \\
\text { Adams, Jr. }\end{array}$ & $\begin{array}{l}\text { Content } \\
\text { Analysis }\end{array}$ & $\begin{array}{l}\text { (1) Actual content present in the message strategy and } \\
\text { framing ads for lenders, like pricing or loan terms are } \\
\text { comparatively rare, (2) Also, significant differences } \\
\text { between informational and transformational themes are } \\
\text { seen. }\end{array}$ \\
\hline $\begin{array}{l}\text { Politics } \\
\text { and Law }\end{array}$ & $\begin{array}{l}\text { Sophie Lechler, } \\
\text { Andreas R. T. } \\
\text { Schuck, Claes H. } \\
\text { de Vreese }\end{array}$ & $\begin{array}{l}\text { Preacher and } \\
\text { Hayes' } \\
\text { INDIRECT } \\
\text { Macro }\end{array}$ & $\begin{array}{l}\text { Effect on the opinion of the students was measured using } \\
\text { enthusiasm, fear, contentment and anger as mediating } \\
\text { variables. When the variables are not controlled, the } \\
\text { result is higher than when directly, the opinion is } \\
\text { measured without mediating variables. }\end{array}$ \\
\hline
\end{tabular}




\begin{tabular}{|c|c|c|c|}
\hline Leadership & $\begin{array}{c}\text { Sandra Honig- } \\
\text { Haftel }\end{array}$ & $\begin{array}{c}\text { Narrative } \\
\text { Review }\end{array}$ & $\begin{array}{c}\text { Framing increases the chances of achievement of } \\
\text { purposive communication. Managers should develop } \\
\text { sensitivity to the context as the interpretation of context } \\
\text { occurs at a subconscious level. }\end{array}$ \\
\hline Leadership & Amber L. Suthers & Survey & $\begin{array}{l}\text { Officer responsible for communication within the } \\
\text { hospitals stated that a plan is always in action. } 93.8 \% \text { of } \\
\text { the employees mentioned that the internal } \\
\text { communication system is key to timely notification about } \\
\text { the hospital changes and the notice of hospital changes } \\
\text { to all the employees. However, feedback systems in } \\
\text { action were ineffective. More barriers to communication } \\
\text { exist in urban hospitals. There is a link between } \\
\text { employee stress and poor communication. }\end{array}$ \\
\hline Leadership & Slaheddine Mnasri & Theses & $\begin{array}{l}\text { Usually, the differences between words said, and they } \\
\text { understood to go hand in hand with the failed framing } \\
\text { attempts. }\end{array}$ \\
\hline Leadership & Jolanta Aritz & & $\begin{array}{l}\text { Discourse is crucial to communication as an expression } \\
\text { of one's thoughts is limited by the social } \\
\text { constructs/groups. Mental Models, however, can be } \\
\text { developed with experience. }\end{array}$ \\
\hline Leadership & Gail T. Fairhurst & & $\begin{array}{l}\text { (1) Arguments in social constructionism over } \\
\text { essentialism, agency and relativism are open for framing, } \\
\text { (2) Managers use that logics to deliver and receive } \\
\text { messages will impact framing ability, (3) Framing is a } \\
\text { teachable skill }\end{array}$ \\
\hline
\end{tabular}

\section{DISCUSSION}

One common and crucial influencing tool which affects the consumer behaviour is 'Self persuasion' which increases the tipping behaviour towards the arguments the consumer makes. Provided with anti-smoking arguments, the consumer starts defending his/her behaviour towards the act of smoking. Self-persuasion is better than planned injunctive norms that are not more subjective to behaviour (StefanF.Bernritter, 2017). When people are in the negative state of mind, they tend to listen more of positively framed sentences rather than listening to the negatively framed sentences. So, framing needs to be done according to the situation and foresee the right consequences (Punam Anand Keller I. M., 2003). In today's modern world of communication, the consumer is raised to see pictorial advertisements and receive information. Hence, the pictorial information/advertising (includes both framed and unframed ads and the characterized and the not characterized ads). It is found that content-based ads are more analyzed and, to experience the goods, unframed ads are used, but only with the characterized message content. However, the characterized ads gain their value by associating the advertised brand with a positivelyvalenced object, person, place, or situation (Terence A. Shimp, 1998). A leader and the leadership are the highly discussed topics of all the times. What makes an effective leader? Framing and Communication! Use of framing in leadership and communication, where strategic communication comes into the picture. Framing plays an essential role in leadership communication. Defining framing in the context of leadership communication; explaining how framing a meaning-making tool is discussing the importance of framing in contemporary organizations; and examining the process of framing analysis (Mnasri, 2008).

For the enhancement of consumer health, quite interesting marketing strategies have to be adopted. By combining framed messages and regulatory focus, healthy advertisements can be manipulated. Anticipating the viewer focus was not necessary and the advertisements become effective when the message attracts the focus of the audience. Direct advertisement is feasible for health-advocating messages without the need to prompt viewers for the adoption of a specific focus (Yeh, 2017).

While framing the information, it can be done in two ways. First, individual consumer's experience is measured by alternately labelling the product (positive or negatively attributing) after the consumers consume the product. 


\section{Chandan R Honavar, Krishna Bhargav K L, and Dr Theresa Nithila Vincent}

Second, by reducing the effect of framing or labelling when consumers get to check the sample as compared to when they did not. At this point, the combined source of information causes the effect of framing to decrease gradually (Gaeth, 1998). Millennials in Philippines are affected by positively-framed messages. Based on the three themes, rationality, frugality, and enticement, this is more evident. Logical reasoning before buying a product, concept of being economical and practical in using his/her money before buying a product and a provocative statement or offer being made to the buying consumer, are the observations made. The millennials usually prefer a positive goal framing. It is believed that the above three themes, along with the positive framing, are more cost-saving and effective (Ma. Criselda M. Tengco-Pacquing, 2019). While targeting the general audience, the lenders prefer using positive framing in their advertisements for the mortgage loans they lend and to give information regarding the pricing or loan terms. Concerning African-American and Hispanic/Latino markets in the USA, use of informational ads well-received in Hispanic/Latino media and the advertisers are more prone to place the negatively framed messages in the African-American media (Vanessa G. Perry, 2016). To avoid smoking and promote anti-smoking campaigns, researchers believe that positively framed messages and agency thinking affect the behaviour of the smoker by infusing positive attitude in him/her to withdraw smoking rather than using the negatively framed messages.

Along with positive Communication (framing) agency thinking, appraisal efficacy and pathway thinking help achieve this anti-smoking campaign (Yang, 2018). Framing effects that have underlying psychological inputs are known as Cognitive. However, framing can be further controlled by responses collected emotionally. When tested, the two positive emotions (enthusiasm and contentment) and two negative emotions (anger and fear) as the arbitrator of the effects of framing, surprisingly the result showed that anger and enthusiasm go together (can mediate framing effects) whereas, fear and contentment cannot mediate (Sophie Lecheler, 2013).Being bipolar is one of the tendencies of human reasoning.The dual concept of "fast, automatic, and emotional processing" and "slow, controlled and rational processing" is seen in framing model, to check whether the textual format is easily perceived or the visual elements of media. The experiments showed that manipulations of the pathway are different from the individual data with individual differences which were more nuanced (Thomas E. Powell, 2018).

The respondents in the study felt that internal communication is very much necessary and crucial for any medical institution. Effective communication is a must, which enhances the internal (organization and employee) relationship also. Feedback is a form of communication that works well with any organization, as it is one of the best practices to date (Suthers, 2017).Framing is seen in all the sectors globally. However, when it comes to health, the research on framing in the field of health is very much limited. Also, the policy process in the health sector has a framing effect on them. The use of single frames and multiple frames in policy process making differs by their usage as one of the exclusion/inclusion criteria. Framing theory also understanding of diseases, policy linkages and also strengthen the health policy covers and other health disciplines (Koon, Hawkins, \& Mayhew, 2015). Market globalization and surrounding competitiveness are creating an increase in the pressure for corporate enterprises to work on their operations, strategies and processing systems. By focusing on project redesigning, the organizations are strengthening their operational systems. The integration of implementation models and life cycles is an area to be looked at and the solutions that organizations have to develop to tackle the issues like "operations strategic management system design, implementation and management" (Edson Pinheiro de Lima, 2008).

Leadership is not everybody's cup of tea, whereas some embrace it as a skill. This is derived from the philosophical thoughts that framing is drawn as a boundary here. This is the first argument, the second one speaks about the manager's ability to frame the logics to frame, produce and positively receive the messages. Expressiveusers speak their mind and are indifferent towards framing skills. Conventional users perceive communication as a challenge; therefore, framing is used to depict the context. Rhetorical users are the most skilled framers because they see communication as the construction and negotiation of social selves and situations. The third argument is whether framing is a teachable skill or not. However, the result was affirmative (Fairhurst, 2005).

\section{FRAMING IN LEADERSHIP COMMUNICATION}

In an interview in 2015, Warren Buffet said, "A relatively modest improvement can make a major difference in your future earning power, as well as in many other aspects of your life". Effective communication can increase one's worth by $50 \%$ as others must follow one's ideas or build on those ideas, especially in the case of a management leader (Elkins, 2019). 


\section{Efficacy of Basalt and Granite as Coarse Aggregate in Concrete Mixture}

Employers, Leaders, Senior Executives, and Managers are people who engage in purposive communication and act as the agents of the organization. Managers are expected to motivate people towards achieving a common goal, more so an organizational goal. Communication skills set an effective manager apart from the other managers. The capability to frame the message in a way to give context effectively is most critical (Raffoni, 2009). Communication differs based on the type, structure of conversation (Centralized and Decentralized) and the organization itself. (Thomas, 2018) provides that it is an arduous task for the communicators to be able to learn different structures and communicate as per the definition of their roles in each of their disciplines.

To train themselves in such a task, Fairhurst (2011) lists a set of questions that the communicators need to answer and assess their capabilities of framing their communication to achieve their individual goals aligned with that of the organizational goals. A leader has to continuously motivate the employees towards achieving the set goal and leaders who are aware and use framing techniques help employees to work towards the goal. The relevance of the set goal to their work is highlighted to remove obstacles by a particular action or by questioning themselves from time to time (Raffoni, 2009). To communicate effectively, the Leader/Manager must connect with the audience and find common ground/common interest. The audience filters what the leader says, which leads to a difference of opinion in what is spoken as opposed to what is understood. Important information about the audience's perspective, perception helps understand people better to manage and lead people. Techniques and skills are more often given more credit, but it is more about the principles and methodologies one chooses to lead and to guide people who look for guidance and direction from time to time. For Managers, Leaders and Influencers, "Perspective" is essential as it is the only thing that differentiates people in the communication process. Broader the perspectives, higher the accuracy of communication (Ramsay \& Cask, 2018). Gary Hamel said that Managers, Department Heads, Team Leaders and Vice presidents spend more time in supervising other's work. However, most organizations are not consistent with what is required of the Manager's position.

The five primary functions of management have been: Planning, Organizing, Staffing, Directing, and Controlling (Fayol). There is more to being a manager than just five essential functions in today's fast-growing economies. Managers are supposed to indulge in activities more creative than repetitive, more mental than manual. Creative thinking helps in expanding the employees' thinking than restrict it to help develop their decision making and thinking. Managers gain perspectives of others and diversify their thinking style to face the challenges by way of experimentation and brainstorming. Managers tend to focus on what is rather than what can be. Success must not distract Innovation. Better ways to grow by reimagining the way one operates the business through practising reflection. Managers need to think like entrepreneurs who will expand their perception and avoid oversight (Pistrui \& Dimov, 2018).

\section{CONCLUSION}

We reviewed many articles and are aware of the fact that we may have missed some articles. The focus of this paper was throwing light into framing and how it can be a part of leadership training with regards to leadership communication. There is a shift in focus from traditional functions of a business process to applying many methodologies in each of the functions like HR, finance, manufacturing and even implementations of ERP system (Casanova, Dider; et al, 2019). This methodology has pierced through leadership in 2018 in forms of agile development. To build an agile culture, leaders should assist in inspiring creativity within employees. Being resilient and having a growth mindset helps in continuous learning as pointed out earlier. As leaders need to adapt to the changing environment and employees within the organization, framing becomes quintessential to the communication aspect of leadership.

Under all the studies conducted with framing as the concept, we observed that each article first defines the concept for their research purpose. So, researchers in the field of communication can research for a standardized definition for framing as there is no standard meaning for this concept. Most studies conducted are either review papers or empirical studies, so framing can be studied with a broader perspective to apply in other functions of business processes concerning the study of social sciences. In totality, ethical framing without the indulgence in manipulative framing can arm the leaders with the greatest weapons of the $21^{\text {st }}$ century in a dynamic organizational culture in a changing environment. 
Chandan R Honavar, Krishna Bhargav K L, and Dr Theresa Nithila Vincent

\section{SOURCES OF FUNDING}

This research received no specific grant from any funding agency in the public, commercial, or not-for-profit sectors.

\section{CONFLICT OF INTEREST}

The author have declared that no competing interests exist.

\section{ACKNOWLEDGMENT}

None.

\section{REFERENCES}

[1] Arowolo, 0. (2017). Understanding Framing Theory. ResearchGate.

[2] Benjamin A. Toll, P. S. (2008). Message framing for smoking cessation: The interaction of risk perceptions and gender. Nicotine \& Tobacco Research.

[3] Burgers, C., Konijn, E. A., \& Steen, G. (2016). Figurative Framing: Shaping Public Discourse Through Metaphor, Hyperbole, and Irony. Communication Theory, 410-430.

[4] Carucci, R. (2018). When Companies Should Invest in Training Their Employees - and When They Shouldn't. Harvard Business Review.

[5] Casanova, Dider; et al. (2019, August). Agile in enterprise resource planning: A myth no more. Retrieved from McKinsey: https://www.mckinsey.com/business-functions/mckinsey-digital/our-insights/agile-inenterprise-resource-planning-a-myth-no-more\#

[6] Choi, J., Lee, K., \& Ji, Y.-Y. (2012). What type of framing message is more appropriate with nine-ending pricing? Marketing Letters.

[7] Conger, J. A. (1998). The Necessary Art of Persuasion. Harvard Business Review.

[8] Edson Pinheiro de Lima, S. E. (2008). Framing Operations and Performance Strategic Management System Design Process. Brazilian Journal of Operations \& Production Management.

[9] Elkins, K. (2019, August 30th). Warren Buffett: Developing this skill can make 'a major difference in your future earning power'.

[10] Entman, R. M. (1993). Framing: Toward Clarification of a Fractured Paradigm. Journal of Communication.

[11] Fairhurst, G. T. (2005). Reframing the Art of Framing: Problems and Prospects for Leadership. 21.

[12] Fairhurst, G. T. (2011). The Power of Framing: Creating the Language of Leadership. San Francisco: JosseyBass.

[13] Fayol, H. (1916). Administration Industrielle et Generale.

[14] Gaeth, I. P. (1998). How Consumers are Affected by the Framing of Attribute Information Before and After Consuming the Product. Journal of Consumer Research, 6.

[15] Gorp, B. V. (2007). The Constructionist Approach to Framing: Bringing Culture Back In. Journal of Communication.

[16] Harrell, E. (2019, November-December). Persuasion - and Resistance. Influence.

[17] Honig-Haftel, S. (1996). The Art of Framing: Managing the Language of Leadership. Academy of Management.

[18] HRZone. (n.d.). What is Learning and Development? Retrieved from HRZone: https://www.hrzone.com/hrglossary/what-is-learning-and-development

[19] Kahneman, D., \& Frederick, S. (2002). Representativeness revisited: Attribute substitution in intuitive judgment. Heuristics and Biases: The Psychology of Intuitive Judgment. Cambridge: Cambridge University Press., 49-81.

[20] Koon, A. D., Hawkins, B., \& Mayhew, S. H. (2015). Framing and the health policy process: a scoping review. Health Policy and Planning, 16. 
[21] Li, K., \& Rifon, N. (2017). The Effects of Message Framing and Reference Points of Public Service Announcements on Bystander Intervention in College Students' Binge-Drinking. Advances in Advertising Research (Vol. VII), 215-229.

[22] Ma. Criselda M. Tengco-Pacquing, R. N. (2019). Positive Framing Effect: A Mixed Method Study on the Buying Behavior of Filipino Millennials. North American Journal of Psychology, 15.

[23] McCombs, M. (1997). Building Consensus: The News Media's Agenda-Setting Roles. Political Communication.

[24] Mnasri, S. (2008, June 05). Framing in Leadership Communication: Strategies, Breakdowns and Outcomes. Framing in Leadership Communication: Strategies, Breakdowns and Outcomes. South Florida, Florida.

[25] O'Keefe, B. J. (1998). The logic of message design: Individual differences in reasoning about communication. Communication Monographs, 80-103.

[26] Pistrui, J., \& Dimov, D. (2018). The Role of a manager has to change in 5 key ways. Harvard Business Review.

[27] Punam Anand Keller, I. M. (2003). Affect, Framing, and Persuasion. Journal of Marketing Research, 10.

[28] Punam Anand Keller, I. M. (2003). Affect, Framing, and Persuasion. Journal of Marketing Research.

[29] Raffoni, M. (2009). How to Frame Your Messages for Maximum Impact. Harvard Business Review.

[30] Ramsay, K., \& Cask, J. (2018, March). Influence: Communication Skills for Management \& Leadership.

[31] Rowley, J., \& Slack, F. (2004). Conducting a literature review. Management Research News.

[32] Shimp, T. A., Urbany, J. E., \& Camlin, S. E. (2013). The Use of Framing and Characterization for Magazine Advertising of Mass-Marketed Products. Journal of Advertising, 23-30.

[33] Sophie Lecheler, A. R. (2013). Dealing with feelings: Positive and negative discrete emotions as mediators of news framing effects. 20.

[34] StefanF. Bernritter, I. a. (2017). Self-persuasion as marketing technique: the role of consumers' involvement. European Journal of Marketing, 15.

[35] Suthers, A. L. (2017). Evaluating Effective Communication Methods: Improving Internal Communication. Evaluating Effective Communication Methods: Improving Internal Communication. East Tennessee State University.

[36] Terence A. Shimp, J. E. (1998). The Use of Framing and Characterization for Magazine Advertising of MassMarketed Products. Journal of Advertising, 07.

[37] Theory, M. C. (2011). Framing Theory. Retrieved from Mass Communication Theory: https://masscommtheory.com/theory-overviews/framing-theory/

[38] Thomas E. Powell, H. G. (2018). Framing fast and slow: a dual processing account of multimodal framing effects. Media Psychology.

[39] Tversky, A., \& Kahneman, D. (1981). The framing of decisions and the psychology of choice. Science Vol. 211, 453-458.

[40] Vanessa G. Perry, C. M. (2016). What's the Point(s)? Information Content and Messaging Strategies in Mortgage Loan Advertisements. US Department of Housing and Urban Development, 21.

[41] Yang, D. J. (2018). Exploring the communication effects of message framing of smoking cessation advertising on smokers' mental processes. International Review on Public and Nonprofit Marketing, 18.

[42] Yeh, C.-Y. L.-J. (2017). How Does Health-Related Advertising with a Regulatory Focus and Goal Framing Affect Attitudes toward Ads and Healthy Behavior Intentions? International Journal of Environmental Research and Public Health, 14.

[43] Younger, J. (2016). How learning and development are becoming more agile. Harvard Business Review. 